\section{Characterizing the Phytotoxic Effects of Hydrogen Peroxide on Common Microgreen Species and Lettuce Cultivars}

\author{
Mitchell Eicher-Sodo ${ }^{1,3}$, Robert Gordon ${ }^{1}$, and Youbin Zheng ${ }^{2}$
}

ADDITIONAL INDEX WORDS. arugula, damage index, greenhouse, irrigation, radish, sunflower

SumMARY. Hydrogen peroxide $\left(\mathrm{H}_{2} \mathrm{O}_{2}\right)$ is an oxidizing agent used to disinfect recirculated irrigation water during the production of organic crops under controlled environmental systems (e.g., greenhouses). To characterize the phytotoxic effects and define a concentration threshold for $\mathrm{H}_{2} \mathrm{O}_{2}$, three microgreen species [arugula (Brassica eruca ssp. sativa), radish (Raphanus sativus), and sunflower (Helianthus annums Black Oil')], and three lettuce (Lactuca sativa) cultivars, Othilie, Xandra, and Rouxai, were foliar sprayed once daily with water containing $0,25,50,75,100,125,150$, or $200 \mathrm{mg} \cdot \mathrm{L}^{-1}$ of $\mathrm{H}_{2} \mathrm{O}_{2}$ from seed to harvest under greenhouse conditions. Leaf damage was assessed at harvest using two distinct methods: 1) the percentage of damaged leaves per tray and 2) a damage index (DI). Applied $\mathrm{H}_{2} \mathrm{O}_{2}$ concentrations, starting from $25 \mathrm{mg} \cdot \mathrm{L}^{-1}$, increased the percentage of damaged leaves in every species except 'Black Oil' sunflower, which remained unaffected by any applied concentration. Symptoms of leaf damage manifested in similar patterns on the surface of microgreen cotyledons and lettuce leaves, while mean DI values and extent of damage were unique to each crop. Fresh weight, dry weight, and leaf area of all crops were not significantly affected by daily $\mathrm{H}_{2} \mathrm{O}_{2}$ spray. Identifying how foliar $\mathrm{H}_{2} \mathrm{O}_{2}$ damage manifests throughout the crop, as well at individual cotyledon or leaf surfaces, is necessary to establish an upper concentration threshold for $\mathrm{H}_{2} \mathrm{O}_{2}$ use. On the basis of the aforementioned metrics, maximum recommended concentrations were $150 \mathrm{mg} \cdot \mathrm{L}^{-1}$ (radish), $100 \mathrm{mg} \cdot \mathrm{L}^{-1}$ (arugula) for microgreens and $125 \mathrm{mg} \cdot \mathrm{L}^{-1}$ ('Othilie'), $75 \mathrm{mg} \cdot \mathrm{L}^{-1}$ ('Rouxai'), and $125 \mathrm{mg} \cdot \mathrm{L}^{-1}$ ('Xandra') lettuce.

$\mathrm{R}$ eusing nutrient solution provides a unique, but challenging prospect within organic greenhouse production due to the restricted number of available pathogen control products. Oxidizing agents, such as ozone, peracetic acid, or hydrogen peroxide; organic acids such as citric or lactic acids and chlorine dioxide are approved for Canadian greenhouse production systems (Government of Canada, 2018). Although the mode of

Received for publication 21 Dec. 2018. Accepted for publication 2 Feb. 2019

Published online 5 April 2019

We thank Michelle Edwards for her statistical support with this study. We also thank the Zheng Laboratory group at the University of Guelph for their various contributions to this publication. This paper makes up part of the Master of Science thesis submitted by Mitchell Eicher-Sodo to Wilfrid Laurier University.

${ }^{1}$ Department of Geography and Environmental Studies, Wilfrid Laurier University, Waterloo, ON, N2L 3C5, Canada

${ }^{2}$ School of Environmental Sciences, University of Guelph, Guelph, ON, NIG 2Wl, Canada

${ }^{3}$ Corresponding author. E-mail: meichersodo@gmail. com.

This is an open access article distributed under the CC BY-NC-ND license (https://creativecommons.org/ licenses/by-nc-nd/4.0/).

https://doi.org/10.21273/HORTTECH04255-18 action varies among products, all provide varying degrees of pathogen control based on concentration, stability, and water quality of the nutrient solution (Raudales et al., 2014a). When choosing a disinfectant, the cost of $\mathrm{H}_{2} \mathrm{O}_{2}$ is significantly less than that of ozone, or chlorine dioxide due to the lack of specialized equipment required for use (Raudales et al., 2014b).

In solution, $\mathrm{H}_{2} \mathrm{O}_{2}$ readily breaks down to hydroxyl radicals $\left(\mathrm{OH}^{-}\right)$and oxygen, making it an ideal component of any "green" chemistry program (Carrasco and Urrestarazu, 2010). The generation of $\mathrm{OH}^{-}$from $\mathrm{H}_{2} \mathrm{O}_{2}$ provides direct control over pathogens and algae within irrigation water, although applied concentrations and contact periods varied between trials (Baldry, 1983; Bosmans et al., 2016; Raudales et al., 2014a; Runia, 1995; Vanninen and Koskula, 1998; Van Wyk et al., 2012). $\mathrm{H}_{2} \mathrm{O}_{2}$ concentrations as low as $37 \mathrm{mg} \cdot \mathrm{L}^{-1}$ for $15 \mathrm{~min}$ (Elmer, 2008) and as high as $200 \mathrm{mg} \cdot \mathrm{L}^{-1}$ for $24 \mathrm{~h}$ (Ehret et al., 2001) have been found to provide similar levels of control for Fusarium $\mathrm{sp}$. in deionized water. Exposure to $400 \mathrm{ppm}$ of $\mathrm{H}_{2} \mathrm{O}_{2}$ for $60 \mathrm{~min}$ removed $99.97 \%$ of tomato mosaic virus (Tobamovirus) cells, whereas exposure to $100 \mathrm{ppm}$ for $5 \mathrm{~min}$ eliminated Fusarium oxysporum conidia (Runia, 1995). Within a greenhouse irrigation system, $100 \mathrm{ppm}$ of $\mathrm{H}_{2} \mathrm{O}_{2}$ reduced free-living and biofilmassociated rhizogenic Agrobacterium by 3.7 and $3.5 \log \mathrm{cfu} / \mathrm{mL}$, respectively, after 72 -h exposure (Bosmans et al., 2016). Against nematodes, application of $400 \mathrm{ppm}$ for $24 \mathrm{~h}$ eliminated burrowing nematode (Radopholus similis) within recirculated irrigation water (Runia and Amsing, 1996). These rates support manufacturer-recommended concentrations of either stabilized or pure, $\mathrm{H}_{2} \mathrm{O}_{2}$ products for disinfecting plant pathogens found in irrigation water (Raudales et al., 2014a). Improving pathogen control at recommended rates requires the maintenance of relatively stable concentrations of $\mathrm{H}_{2} \mathrm{O}_{2}$, which is better achieved through repeated dosing of irrigation water, rather than an increase in disinfectant concentration (Copes, 2009). Once-daily injections of $30 \mathrm{ppm} \mathrm{H}_{2} \mathrm{O}_{2}$ decreased the number of hairy root disease (Agrobacterium) infested 'Kanavaro' tomato (Solanum lycopersicum) plants by $20 \%$ within a commercial irrigation circuit after 12 weeks (Bosmans et al., 2016). Similar effects were observed when $\mathrm{H}_{2} \mathrm{O}_{2}$ foliar spray applications increased from one to five times per week, with both severity and incidence of Puccinia

\begin{tabular}{llll}
\hline $\begin{array}{l}\text { Units } \\
\text { To convert U.S. to SI, } \\
\text { multiply by }\end{array}$ & U.S. unit & SI unit & $\begin{array}{l}\text { To convert SI to U.S., } \\
\text { multiply by }\end{array}$ \\
\hline 29.5735 & $\mathrm{fl} \mathrm{oz}$ & $\mathrm{mL}$ & 0.0338 \\
3.7854 & gal & $\mathrm{L}$ & 0.2642 \\
2.54 & inch(es) & $\mathrm{cm}$ & 0.3937 \\
6.4516 & inch $^{2}$ & $\mathrm{~cm}^{2}$ & 0.1550 \\
28.3495 & $\mathrm{Oz}$ & $\mathrm{g}$ & 0.0353 \\
1 & $\mathrm{ppm}$ & $\mathrm{mg} \cdot \mathrm{L}^{-1}$ & 1 \\
6.8948 & $\mathrm{psi}$ & $\mathrm{kPa}$ & 0.1450 \\
$\left({ }^{\circ} \mathrm{F}-32\right) \div 1.8$ & ${ }^{\circ} \mathrm{F}$ & ${ }^{\circ} \mathrm{C}$ & $\left({ }^{\circ} \mathrm{C} \times 1.8\right)+32$ \\
& & & \\
\hline
\end{tabular}


bemerocallidis reduced on 'Pardon Me' daylily (Hemerocallis) leaves (Copes, 2009). Consistent dosing of water with $\mathrm{H}_{2} \mathrm{O}_{2}$ leads to the exposure of crops to $\mathrm{H}_{2} \mathrm{O}_{2}$ during irrigation events and brings the potential for a phytotoxic response if excessive concentrations are circulated.

Exposure of crops to $\mathrm{H}_{2} \mathrm{O}_{2}$ is directly based on the irrigation method used. Overhead irrigation, using spray nozzles attached to automated booms, is employed for production of microgreens, and lettuce in southwestern Ontario, Canada. Microgreens, seeded in shallow trays onto the growing substrate, use overhead irrigation to achieve even watering across the tray surface. These types of irrigation techniques result in exposure to $\mathrm{H}_{2} \mathrm{O}_{2}$ as water is sprayed directly onto the foliage of the crop during each irrigation event. With microgreens being harvested anywhere from 6 to $21 \mathrm{~d}$ after seeding, any phytotoxic symptoms from $\mathrm{H}_{2} \mathrm{O}_{2}$ use would manifest rapidly because these young crops have not hardened against environmental stressors (Viršilè and Sirtautas, 2013 ).

Evaluating the phytotoxic potential of $\mathrm{H}_{2} \mathrm{O}_{2}$ yielded surprisingly limited research concerning damage from foliar spray applications. Alfalfa (Medicago sativa) sprouts, foliar sprayed with $\mathrm{H}_{2} \mathrm{O}_{2}$ concentrations from 200 to $1000 \mathrm{mg} \cdot \mathrm{L}^{-1}$ via a misting head, experienced no leaf damage or decrease in growth (Fett, 2002). In contrast, $\mathrm{H}_{2} \mathrm{O}_{2}$ phytotoxic effects were reported at concentrations as low as 9 and $12 \mathrm{mg} \cdot \mathrm{L}^{-1}$, when applied every $6 \mathrm{~h}$, resulting in the yellowing of radish and garden cress (Lepidium sativum) (Coosemans, 1995). Lettuce seedlings exposed to $8 \mathrm{mg} \cdot \mathrm{L}^{-1}$ $\mathrm{H}_{2} \mathrm{O}_{2}$ for $24 \mathrm{~h}$ experienced a decrease in growth, whereas application of 85 $\mathrm{mg} \cdot \mathrm{L}^{-1}$ over $24 \mathrm{~h}$ resulted in seedling death (Nederhoff, 2000). Exposure to $500 \mathrm{mg} \cdot \mathrm{L}^{-1}$ was reportedly harmful to plant roots, although application methodology and species information were withheld (Van OS, 1999). Within the listed studies, neither the volumes of applied irrigation water nor the degree of phytotoxicity respective to the given plant species were reported. However, phytotoxicity in the form of leaf senescence has been described in nursery crops exposed to 3.4 to $10 \mathrm{~g} \cdot \mathrm{L}^{-1}$ after one to three foliar applications of $\mathrm{H}_{2} \mathrm{O}_{2}$ (Copes et al., 2003). These studies highlight the requirement of research to accurately characterize the degree of $\mathrm{H}_{2} \mathrm{O}_{2}$ phytotoxicity displayed by plants after repeated foliar applications of irrigation water augmented with $\mathrm{H}_{2} \mathrm{O}_{2}$. Further, they provide a framework for concentrations at which $\mathrm{H}_{2} \mathrm{O}_{2}$ may cause phytotoxic effects on young crops grown under greenhouse conditions.

This study was conducted to identify how organic microgreens and lettuce plug $(21 \mathrm{~d})$ crops respond to daily foliar spray with $\mathrm{H}_{2} \mathrm{O}_{2}$ at concentrations commonly used to control plant pathogens within irrigation water. The results were used to assess an upper threshold at which $\mathrm{H}_{2} \mathrm{O}_{2}$ can be applied to these crops without a reduction in market quality and physiological growth.

\section{Materials and methods Plant materials}

On 20 Mar. 2018, 72 compostable trays (The HC Companies, Twinsberg, $\mathrm{OH}$ ) were seeded with one of three organic certified microgreen species [arugula, radish, and 'Black Oil' sunflower (Mumm's Sprouting Seeds, Parkside, SK, Canada)] and eight 72-cell lettuce plug trays (A.M.A Plastics, Kingsville, ON, Canada) were seeded with three lettuce cultivars; Othilie, Rouxai, Xandra (RZH Canada, Leamington, ON, Canada), in each plug, by a local organic greenhouse grower (Hamilton, ON, Canada). Two peat-based substrates (Fafard et Freres, Saint-Bonaventure, QC, Canada) were used, each of which consisted of a proprietary blend of peat, organic compost, and granular fertilizer tailored for either microgreens or lettuce. Lettuce and microgreen trays were machine filled with the required substrate. Microgreen seeds were then sown directly onto the substrate surface in the following quantities: arugula at $3.3 \mathrm{~g} /$ tray, radish at $21 \mathrm{~g} /$ tray, and 'Black Oil' sunflower at $94 \mathrm{~g} /$ tray. Microgreen and lettuce seeds were then covered in a thin layer of coconut coir (Projar, Valencia, Spain). Immediately after sowing, trays were transported less than $\mathrm{l} h$ from the commercial greenhouse to the University of Guelph (Guelph, ON, Canada; lat. $43^{\circ} 33^{\prime} \mathrm{N}$, long. $80^{\circ} 15^{\prime} \mathrm{W}$ ) and stored in a $4^{\circ} \mathrm{C}$ cold room for $48 \mathrm{~h}$ before the trial start.

\section{Growing conditions}

The trial took place at the University of Guelph research greenhouses and was conducted from 22 Mar. 2018 through 12 Apr. 2018 $(21 \mathrm{~d})$. Over the course of the trial, air temperature inside the greenhouse averaged $20.1{ }^{\circ} \mathrm{C}$, and the relative humidity averaged $43.1 \%$. Only natural lighting was provided over the course of the trial period.

\section{Experimental setup}

Each microgreen tray $\left(1250 \mathrm{~cm}^{2}\right)$ was divided into two experimental units $\left(625 \mathrm{~cm}^{2}\right)$ using a movable plastic shield $(25 \times 12.5 \times 20 \mathrm{~cm})$ to allow for the application of two separate treatments per tray. The 72-cell lettuce plug trays were cut into six experimental units, consisting of 12 plugs each. Lettuce experimental units each received a single treatment and were separated during treatment application by the aforementioned shield to prevent spray drift. Individual species of microgreens were grouped together to form three segregated clusters on the bench surface. Lettuce plugs were also placed adjacent to one another in a fourth cluster of crops. This increased irrigation uniformity, and reduced the required bench space within the greenhouse. Treatments were applied to each cluster using a completely randomized design created with the agricolae package in $\mathrm{R}$ (version 3.50 ; R Foundation for Statistical Computing, Vienna, Austria). Each of the eight treatments was replicated six times, resulting in 48 experimental units per microgreen species and the lettuce plugs. Experimental units were rotated within a cluster every $3 \mathrm{~d}$ using a randomized design.

\section{Hydrogen peroxide treatment}

Plants were foliar sprayed daily with one of the following freshly made solutions (with deionized water) $[0$ (control) $25,50,75,100$, 125,150 , and $\left.200 \mathrm{mg} \cdot \mathrm{L}^{-1}\right]$ of $\mathrm{H}_{2} \mathrm{O}_{2}$. The $\mathrm{H}_{2} \mathrm{O}_{2}$ solutions were diluted from a $3 \%(\mathrm{w} / \mathrm{w})$ stock solution maintained using a $34.5 \%(\mathrm{w} / \mathrm{w})$ barrel (Anchem, London, ON, Canada). The 3\% $(\mathrm{w} / \mathrm{w})$ solution was replaced every 7 d. All $\mathrm{H}_{2} \mathrm{O}_{2}$ solutions were stored in a $4{ }^{\circ} \mathrm{C}$ cooler to prevent 
chemical decomposition. Each $\mathrm{H}_{2} \mathrm{O}_{2}$ solution was confirmed using titration with potassium permanganate as outlined in Klassen et al. (1994).

\section{Treatment protocol}

Treatments began on 22 Mar. 2018 for lettuce plugs, 23 Mar. 2018 for radish, 23 Mar. 2018 for arugula, and 24 Mar. 2018 for 'Black Oil' sunflower to stagger harvest dates. Lettuce plugs received $300 \mathrm{~mL}$ of solution on the first day and $109 \mathrm{~mL}$ each subsequent day until harvest. All microgreen species received $750 \mathrm{~mL}$ of solution on the first day. On subsequent days until harvest, radish, and arugula, received $150 \mathrm{~mL}$ of solution, and 'Black Oil' sunflower received $266 \mathrm{~mL}$ of solution. A 4-gal backpack sprayer (61900-1; Chapin International. Batavia, NY) with a 29-psi control flow valve (Chapin International) attached to an adjustable cone nozzle was used to foliar apply all treatment solutions. Treatments were applied between 20 and 40 psi, and monitored with a pressure gauge attached to the handle to mimic commercial growing techniques. Treatment was applied once per day, regardless of the crop, and this also provided adequate irrigation to each crop.

\section{Harvest protocols}

AsSESSMENT OF THE PERCENTAGE OF DAMAGED LEAVES. The percentage of damaged leaves was determined using the same methodology for each microgreen species. A cylindrical core, consisting of a hollow tube $\left(19.6 \mathrm{~cm}^{2}\right)$, was used for sampling after $6 \mathrm{~d}$ for radish, $11 \mathrm{~d}$ for arugula, and $12 \mathrm{~d}$ for 'Black Oil' sunflower. Microgreens were harvested on emergence of true leaves. To avoid edge effects, cores were sampled within a 1 -inch border around the edge of each experimental unit. The core was pushed through the canopy and into the substrate at three random locations within this border. Microgreens and roots, with attached substrate, were removed from the tray and placed onto a plastic plate. The number of damaged cotyledons, and the total number of cotyledons were counted and recorded separately for each core sample. A cotyledon was considered damaged if any part of the leaf surface was degraded by $\mathrm{H}_{2} \mathrm{O}_{2}$ without discriminating the degree to which damage had occurred. Leaf counts (damaged or total number) were pooled for the three sampled locations, and the number of damaged leaves was divided by total number of leaves to calculate a single proportion for each replicate. Proportions of damaged leaves were averaged across the six replicates per $\mathrm{H}_{2} \mathrm{O}_{2}$ treatment to generate the percentages displayed in Fig. 1. For the lettuce, after $21 \mathrm{~d}$, three lettuce plugs were sampled per tray and the number of damaged and total number of leaves were counted on a per-plug basis. This followed the commercial production practice where after 3 weeks $(21 \mathrm{~d})$, plugs are transplanted to larger pots. Leaf counts were pooled across the three sampled plugs per replicate and the number of damaged leaves divided by the total number of leaves to generate a single proportion per replicate. The proportions were then averaged across the six replicates per treatment level to produce the percentages presented in Fig. 1. Only plugs in which all three lettuce cultivars had sprouted were sampled and leaves from all three lettuce cultivars were counted individually.

EVAlUation OF LEAVES USING THE DI. For each replicate, regardless of the given crop, 10 leaves were randomly harvested between the three microgreen cores or three lettuce plugs previously used to determine the percentage of damaged leaves. Upon visual inspection of the sampled leaves, $\mathrm{H}_{2} \mathrm{O}_{2}$ damage was consistent across the affected crops and fell into five distinct categories. The damage categories are outlined in Table 1. Each of the $10 \mathrm{sam}-$ pled leaves was assigned a value from Table 1 to qualitatively assess damage on the leaf surface. Values from the 10 sampled leaves were pooled across the six replicates within each treatment level and averaged per treatment to generate the values presented in Fig. 2. Harvested leaves were kept with their original cores or plugs to be included within growth measurements.

Growth parameters. Fresh weights for microgreen species were collected on a per replicate basis by harvesting whole plants at a height of 0.5 inch above the substrate surface from the same three cores sampled for the percentage of damaged leaves. Growth measurements began immediately after DI value assessment to limit wilting. One fresh weight was recorded per replicate using all plants from the three sampled cores. Leaf area was recorded by selecting 10 random plants used for fresh weight from each replicate and removing the cotyledons at the petiole. Twenty individual cotyledons were passed through a leaf area meter (LI-300; LI-COR, Lincoln, NE), and a single value in square centimeters was recorded per replicate. All cut cotyledons, their petioles and stems, were gathered with other fresh cut plants of the same replicate before being placed into labeled paper bags. The bags were then left in a drying oven at $80^{\circ} \mathrm{C}$ for $3 \mathrm{~d}$ until a consistent weight was reached, and one dry weight per replicate was recorded. Fresh weights, dry weights, and leaf areas were averaged across the six replicates to generate the values in Table 2.

Previously sampled plugs for the three lettuce cultivars, Othilie, Rouxai, and Xandra, had all leaves harvested at the soil line, and were separated by cultivar for weighing. All leaves of a single cultivar from the sampled plugs were pooled together such that one fresh weight value was recorded for each replicate. The same leaves were then passed through the leaf area meter, and a single leaf area in square centimeters was recorded per replicate. Leaves were then placed into paper bags and inserted into an 80 ${ }^{\circ} \mathrm{C}$ drying oven for $3 \mathrm{~d}$ until they reached a consistent weight. A single dry weight for each replicate was recorded. These steps were repeated for the remaining two lettuce cultivars, and data were averaged across the six replicates to produce the values under each treatment level in Table 2.

Statistical analysis. For the percentage of damaged leaves per tray, chi-square test of independence was performed to detect whether there were treatment effects between treatment levels. If treatment effects were significant $(P \leq 0.05)$, contrasts were generated between treatments using estimated marginal means to evaluate differences as part of the emmeans package in $\mathrm{R}$ (version 3.50). For DI values, a Kruskal-Wallis test was performed to detect whether there were treatment effects. When 

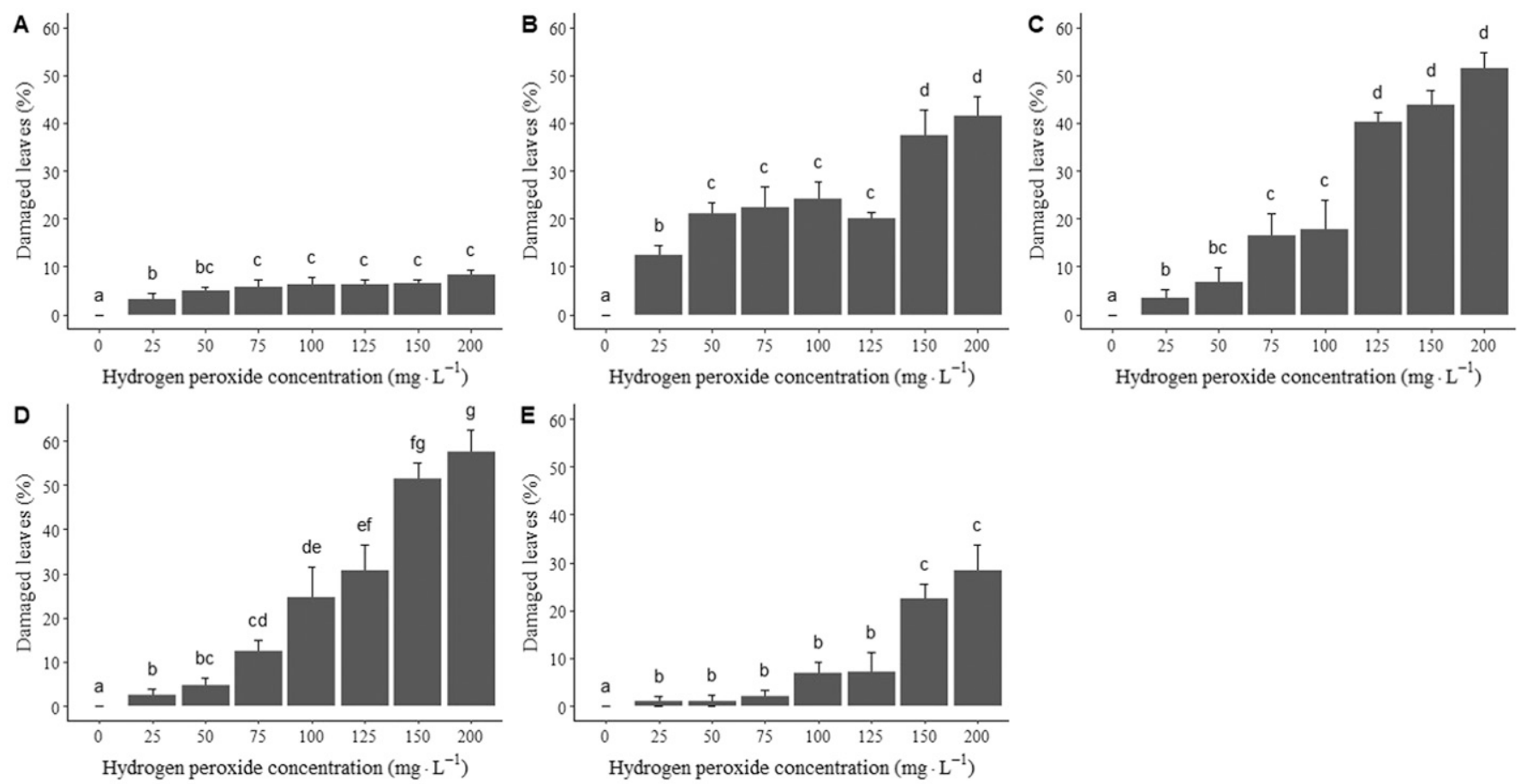

Fig. 1. Percentage of damaged leaves for two microgreen species (arugula, radish) and three lettuce cultivars (Othilie, Rouxai, Xandra) after daily foliar spray with one of eight hydrogen peroxide concentrations $(0,25,50,75,100,125,150$, or 200 $\left.\mathrm{mg} \cdot \mathrm{L}^{-1}\right)$. Percentages were generated by dividing the pooled values for the total number of leaves by the number of damaged leaves within three cores $\left[3 \mathrm{inch}^{2}\left(19.63 \mathrm{~cm}^{2}\right)\right]$ or three lettuce plugs sampled from each replicate. Each core, or plug, represented a subsample, and each bar represents the mean of six replicates (three subsamples per replicate) \pm SE. Percentages were generated by crop for (A) radish, (B) arugula, (C) 'Othilie', (D) 'Rouxai', and (E) 'Xandra'. Bars bearing the same letter within the same species or cultivar were not significantly different $(P \leq 0.05)$ by chi-square test of independence; $1 \mathrm{mg} \cdot \mathrm{L}^{-1}=$ $1 \mathrm{ppm}$.

Table 1. Damage index (DI) used to assign qualitative values to each microgreen species (radish, arugula, and 'Black Oil' sunflower) species and lettuce cultivars (Othilie, Rouxai, Xandra). Values represent the types of damage that emerged on cotyledons or leaves after daily foliar spray with one of eight concentrations $[0$, $25,50,75,100,125,150$, or $\left.200 \mathrm{mg} \cdot \mathrm{L}^{-1}(\mathrm{ppm})\right]$ of hydrogen peroxide.

\begin{tabular}{|c|c|}
\hline$\underline{\text { DI value }}$ & Appearance of leaf surface \\
\hline 0 & No degradation of leaf cuticle at any location on leaf surface. \\
\hline 1 & $\begin{array}{l}\text { Formation of small spots or areas on, or just inside, the outer edges of the } \\
\text { leaf surface. Damaged spots appear as darkened areas against the leaf } \\
\text { background. }\end{array}$ \\
\hline 2 & $\begin{array}{l}\text { Progression in location and size of damaged spots or areas from outer leaf } \\
\text { edges onto inner leaf surfaces. Damaged spots or areas may begin } \\
\text { browning slightly. }\end{array}$ \\
\hline 3 & $\begin{array}{l}\text { Formation of a "band" of damaged spots or single larger area between the } \\
\text { outer edges of the leaf surface progressing toward base of leaf. Spots or } \\
\text { areas may be turning slightly brown or necrotic. }\end{array}$ \\
\hline 4 & $\begin{array}{l}\text { Damage has advanced down toward the petiole of the leaf beyond the estimated } \\
\text { central point of the leaf. Spots or damaged areas may be necrotic. }\end{array}$ \\
\hline
\end{tabular}

treatment effects were detected, a multiple comparisons of means $(P \leq$ $0.05)$ was conducted using a Fisher least squares difference test as part of the agricolae package in $\mathrm{R}$. Growth parameters were analyzed using analysis of variance (ANOVA) from the agricolae package in $\mathrm{R}$.

\section{Results}

Visible DAMAge. $\mathrm{H}_{2} \mathrm{O}_{2}$ phytotoxic symptoms manifested in similar patterns, although the appearance differed, for the two microgreen species and three lettuce cultivars affected by the applied treatments
(Table 1); 'Black Oil' sunflower was unaffected by any $\mathrm{H}_{2} \mathrm{O}_{2}$ treatment. Lettuce leaf damage manifested as circular shaped areas regardless of the assigned DI value. As $\mathrm{H}_{2} \mathrm{O}_{2}$ damage increased, the three lettuce cultivars exhibited necrotic browning, although this remained difficult to distinguish against the background leaf color. Affected areas on microgreen cotyledons continuously darkened against surrounding cotyledon tissue color as DI values rose. Damaged areas appeared "wet" on the cotyledons and manifested in irregular shapes when compared with the lettuce cultivars. The visibility of $\mathrm{H}_{2} \mathrm{O}_{2}$ damage varied between the six crops, with damaged areas on 'Rouxai' lettuce being most visible against the dark red plant tissue. Damaged areas on 'Othilie' leaves were the least visible of any crop, with $\mathrm{H}_{2} \mathrm{O}_{2}$ damage providing little contrast against light green leaf tissue. Visibility of leaf damage in the remaining crops decreased in the following order: radish, arugula, and 'Xandra' lettuce. 

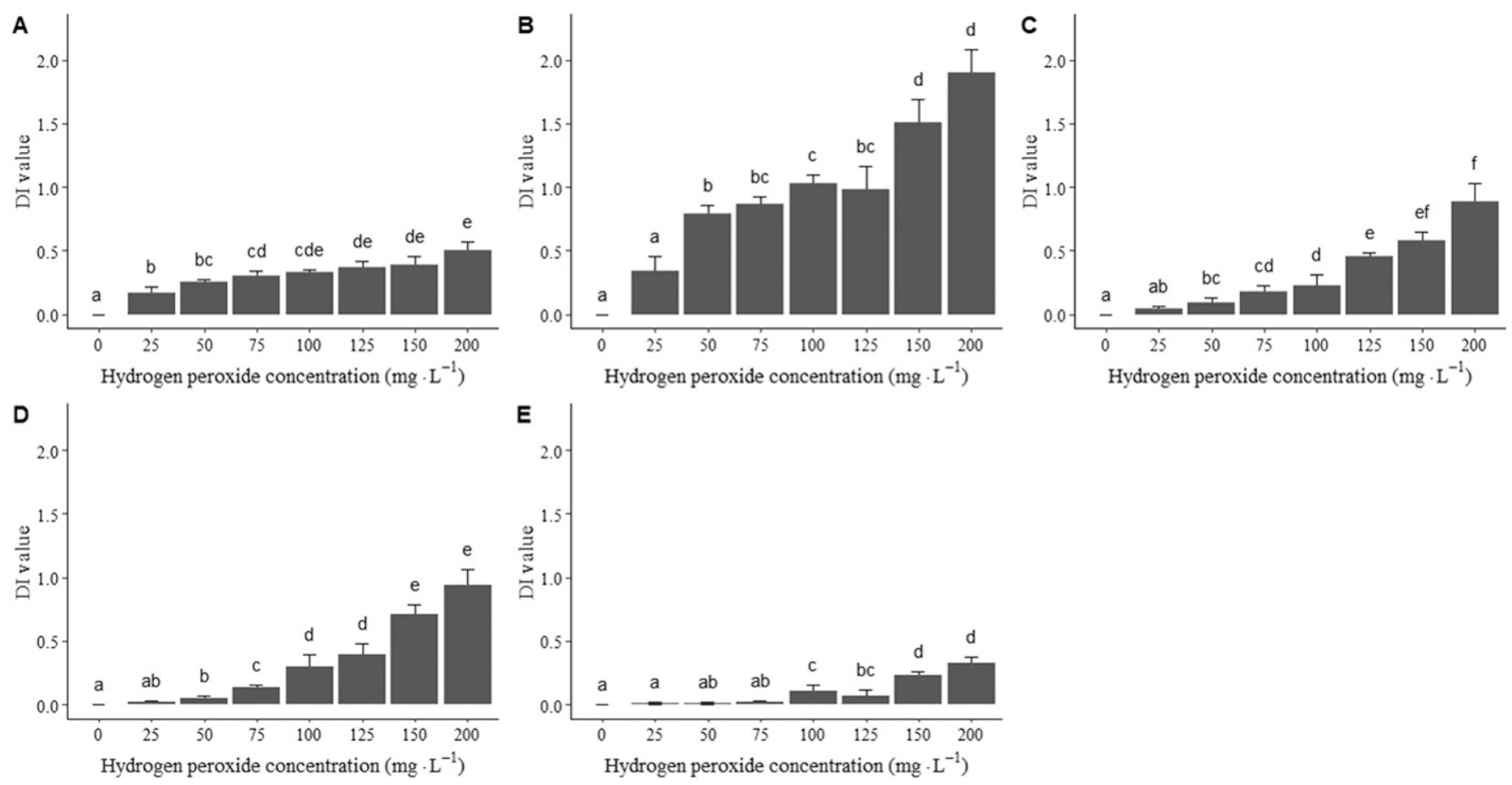

Fig. 2. Average damage index (DI) values for two microgreen species (radish, arugula) and three lettuce cultivars (Othilie, Rouxai, Xandra) after daily foliar spray with one of eight concentrations of hydrogen peroxide $(0,25,50,75,100,125,150$, or $\left.200 \mathrm{mg} \cdot \mathrm{L}^{-1}\right)$. DI values were generated by assigning sampled leaves to the categories in Table 1 . DI values were generated by crop for (A) radish, (B) arugula, (C) 'Othilie', (D) 'Rouxai', and (E) 'Xandra'. For each replicate, 10 leaves were randomly selected from three microgreen cores $\left[3 \mathrm{inch}^{2}\left(19.63 \mathrm{~cm}^{2}\right)\right]$ or three lettuce plugs, and each leaf was assigned to a category based on the observed damage. The assigned DI values were pooled across the six replicates so that each bar represents the mean of six replicates \pm SE. Bars bearing the same letter within the same species or cultivar were not significantly different $(P \leq 0.05)$ by the Kruskal-Wallis test; $1 \mathrm{mg} \cdot \mathrm{L}^{-1}=1 \mathrm{ppm}$.

Table 2. Fresh weight, dry weight, and leaf area for three microgreen species (arugula, radish, and 'Black Oil' sunflower) and three lettuce cultivars (Othilie, Rouxai, and Xandra) after daily foliar spray treatment with eight concentrations of hydrogen peroxide $\left[0,25,50,75,100,125,150\right.$, or $\left.200 \mathrm{mg} \cdot \mathrm{L}^{-1}(\mathrm{ppm})\right]$.

\begin{tabular}{lrcc}
\hline & Fresh wt $(\mathrm{g})^{\mathrm{z}}$ & Dry wt $(\mathrm{g})$ & Leaf area $\left(\mathrm{cm}^{2}\right)^{\mathrm{z}}$ \\
\cline { 2 - 4 } Crop & \multicolumn{3}{c}{ mean $\pm \mathrm{sE}^{\mathrm{y}}$} \\
\hline Microgreen species & & \\
$\quad$ Radish & $10.8 \pm 0.240$ & $0.82 \pm 0.013$ & $23 \pm 0.5$ \\
$\quad$ Arugula & $7.4 \pm 0.089$ & $0.41 \pm 0.006$ & $16 \pm 0.3$ \\
$\quad$ 'Black Oil' & $20.2 \pm 0.390$ & $1.57 \pm 0.033$ & $33 \pm 0.4$ \\
Lettuce cultivars & & & \\
Othilie & $0.74 \pm 0.010$ & $0.17 \pm 0.003$ & $23 \pm 0.5$ \\
Rouxai & $0.71 \pm 0.010$ & $0.20 \pm 0.003$ & $31 \pm 0.4$ \\
$\quad$ Xandra & $0.61 \pm 0.007$ & $0.15 \pm 0.003$ & $22 \pm 0.3$ \\
\hline
\end{tabular}

${ }^{\mathrm{z}} 1 \mathrm{~g}=0.0353 \mathrm{oz}, 1 \mathrm{~cm}^{2}=0.1550$ inch $^{2}$.

y Data values are means of the 48 sampled data points pooled for individual crops after no treatment effects were detected using analysis of variance in R (version 3.50; R Foundation for Statistical Computing, Vienna, Austria).

Percentage of Damaged LEAves. The percentage of damaged leaves described the extent of visible damage for microgreen species or lettuce cultivars. The control (0 $\left.\mathrm{mg} \cdot \mathrm{L}^{-1}\right)$ caused no damage to any crop, and maximum damage occurred at $200 \mathrm{mg} \cdot \mathrm{L}^{-1}$ for the affected species. In all species and cultivars, except for 'Black Oil' sunflower, all
$\mathrm{H}_{2} \mathrm{O}_{2}$ treatments showed a significant increase in damage compared with the control, although the percentage varied extensively (Fig. 1). Radish was least affected, with leaf damage reaching a maximum of $8.1 \%$ (Fig. 1A). 'Othilie' and 'Rouxai' lettuce were most affected by $\mathrm{H}_{2} \mathrm{O}_{2}$ treatment and reached maximum damage values of 57\% (Fig. 1C) and 51\% (Fig. 1D), respectively. Maximum damage to arugula of $41 \%$ (Fig. 1B) and 'Xandra' lettuce of $29 \%$ (Fig. 1E), fell between that found for radish and 'Rouxai' lettuce. Percentage of leaf damage to four of the six crops (radish, arugula, 'Othilie', and 'Xandra' lettuce) did not differ significantly between 50 and $100 \mathrm{mg} \cdot \mathrm{L}^{-1}$ of $\mathrm{H}_{2} \mathrm{O}_{2}$ treatment. Damage to 'Rouxai' (Fig. ID) was found to increase significantly between 50 and $100 \mathrm{mg} \cdot \mathrm{L}^{-1}$ of $\mathrm{H}_{2} \mathrm{O}_{2}$ treatment. Increasing concentration from 100 to $150 \mathrm{mg} \cdot \mathrm{L}^{-1}$ resulted in an almost doubling of the percentage of damaged leaves for the affected crops (Fig. 1) other than radish.

DAmage Index. DI values manifested in similar patterns at lower concentrations of $\mathrm{H}_{2} \mathrm{O}_{2}$, and maximum DI values occurred at 200 $\mathrm{mg} \cdot \mathrm{L}^{-1}$ for all affected crops. Treatment with $50 \mathrm{mg} \cdot \mathrm{L}^{-1}$ of $\mathrm{H}_{2} \mathrm{O}_{2}$ caused a significant increase in mean DI value compared with the control for radish (Fig. 2A), arugula (Fig. 2B), 'Othilie' (Fig. 2C), and 'Rouxai' (Fig. 2D) lettuce. Damage to 'Xandra' (Fig. $2 \mathrm{E})$ lettuce was significantly greater 
than the control when treated with $100 \mathrm{mg} \cdot \mathrm{L}^{-1}$ or greater of $\mathrm{H}_{2} \mathrm{O}_{2}$. Arugula was the only tested crop to record a mean DI greater than 1.0 at 100 (DI 1.03), 150 (DI 1.5), and 200 (DI 1.9) $\mathrm{mg} \cdot \mathrm{L}^{-1}$ (Fig. 2B), although mean values remained below DI 2 . DI 3 and 4 values were seldom assigned to arugula cotyledons (data not shown), and arugula DI values were not significantly different when $\mathrm{H}_{2} \mathrm{O}_{2}$ concentration increased from 75 to $125 \mathrm{mg} \cdot \mathrm{L}^{-1}$. Similar to arugula, 'Othilie' and 'Rouxai' lettuce leaves were assigned few DI 3 and DI 4 values (data not shown), reaching maximum values of 0.88 (Fig. 2C) and 0.94 (Fig. 2D), respectively. Mean DI values for 'Rouxai' lettuce were significantly different between 75 and $100 \mathrm{mg} \cdot \mathrm{L}^{-1}$ (Fig. 2D) treatments. In contrast, significant differences in DI values were found for 'Othilie' lettuce treated with 100 and $125 \mathrm{mg} \cdot \mathrm{L}^{-1}$ (Fig. 2C) of $\mathrm{H}_{2} \mathrm{O}_{2}$. Radish DI values did not differ significantly as $\mathrm{H}_{2} \mathrm{O}_{2}$ concentration increased from 100 to $200 \mathrm{mg} \cdot \mathrm{L}^{-1}$, reaching a maximum DI value of 0.53 (Fig. 2A). Radish, 'Othilie', and 'Rouxai' lettuce surpassed the 'Xandra' lettuce maximum DI value of 0.32 (Fig. 2E) at the $125 \mathrm{mg} \cdot \mathrm{L}^{-1}$ treatment level. Similar to the percentage of damaged leaves, a change in concentration from 100 to 150 $\mathrm{mg} \cdot \mathrm{L}^{-1}$ resulted mean DI values almost doubling (Fig. 2) for all affected crops other than radish.

Growth. For any of the crops in the trial, applications of $\mathrm{H}_{2} \mathrm{O}_{2}$ were found to have no significant effect on growth when fresh weights, dry weights, and leaf areas were analyzed using a completely randomized design ANOVA. Thus, growth data for individual microgreen species and lettuce cultivars was pooled across all treatments for each metric and presented in Table 2.

\section{Discussion}

Results from this study demonstrate how daily foliar application of irrigation water containing low concentrations of $\mathrm{H}_{2} \mathrm{O}_{2}$ induce a phytotoxic response for various crops. Foliar damage was unique to each affected crop (Fig. 1A-E), and 'Black Oil' sunflower remained unaffected at any of the tested $\mathrm{H}_{2} \mathrm{O}_{2}$ concentrations. Phytotoxic symptoms of $\mathrm{H}_{2} \mathrm{O}_{2}$ were visible over the treatment range of 25 to $200 \mathrm{mg} \cdot \mathrm{L}^{-1}$ and manifested in similar patterns between affected crops (Table 1). However, leaf area and fresh and dry weights did not differ between $\mathrm{H}_{2} \mathrm{O}_{2}$ treatments for individual microgreen species or lettuce cultivars.

Previous research reported growth benefits when evaluating $\mathrm{H}_{2} \mathrm{O}_{2}$ foliar spray applications at concentrations similar to those in this experiment (Aftab et al., 2011; Ahmad et al., 2014). Within these studies, $\mathrm{H}_{2} \mathrm{O}_{2}$ was applied over an extended time frame compared with the current trial. We did not observe an increase in any growth parameter under the tested conditions, which suggested that, at low concentrations, daily foliar spray with $\mathrm{H}_{2} \mathrm{O}_{2}$ will not hinder crop growth, despite the appearance of leaf damage. However, the short microgreen growth cycle limited interpretation regarding how daily $\mathrm{H}_{2} \mathrm{O}_{2}$ foliar spray affects plant growth over longer time frames. We suspect that daily applications overwhelm the antioxidant enzymes that maintain a tight concentration range of $\mathrm{H}_{2} \mathrm{O}_{2}$ used for cellular signalling processes beneficial to plant growth (Neill et al., 2002; Petrov and Van Breusegem, 2012). Our findings indicate growth parameters should not be relied on to develop an $\mathrm{H}_{2} \mathrm{O}_{2}$ use threshold at the applied concentrations. Instead, the severity of foliar phytotoxicity provided an improved estimate of the threshold for daily applications of $\mathrm{H}_{2} \mathrm{O}_{2}$.

Symptoms of $\mathrm{H}_{2} \mathrm{O}_{2}$ phytotoxicity, displayed in Table 1 , progressed from the outer edges to the center of the leaf surface. Using this knowledge, we consulted a professional greenhouse grower (Hamilton, $\mathrm{ON}$, Canada) to identify when damaged leaves were no longer marketable to consumers. Previous consumer testing, which determined preference for microgreen and lettuce consumption, increased with leaf quality and other desirable sensory attributes, further contributed to this decision (Ares et al., 2008; Xiao et al., 2015). The DI and percentage of damaged leaves were found to accurately characterize $\mathrm{H}_{2} \mathrm{O}_{2}$ phytotoxicity based on these recommendations. DI 3 and 4 values were identified as being undesirable to consumers within our study, although these were well defined only for radish and 'Rouxai' crops. DI 4 values were easily identified for arugula, 'Othilie', and 'Xandra' crops, whereas DI 3 damage may be misidentified as DI 2 damage without careful inspection. DI 1 or 2 leaf damage retained a similar color intensity to the leaf background leaf damage for arugula, 'Othilie', and 'Xandra' crops but were distinctive for radish and 'Rouxai'. The variability in DI values suggests an opportunity exists to misidentify DI 1 or 2 compared with DI 3 or 4 values when investigating $\mathrm{H}_{2} \mathrm{O}_{2}$ damage among multiple crops. Further, computer software, normally used to quantify foliar damage (Graham et al., 2009; James, 1971), could not be applied as $\mathrm{H}_{2} \mathrm{O}_{2}$ damage was not distinctive enough to be recognized by software for any of the affected crops. Quantifying the percentage of damaged leaves per tray, along with the DI of individual leaves, provides a more accurate measure of $\mathrm{H}_{2} \mathrm{O}_{2}$ leaf damage.

The small leaf size of microgreens and lettuce seedlings dictates a time-consuming process to inspect individual leaves for $\mathrm{H}_{2} \mathrm{O}_{2}$ damage. Because the majority of affected crops recorded a mean DI $>1.0$, widespread foliar phytotoxicity from $\mathrm{H}_{2} \mathrm{O}_{2}$ spray better characterized excessive $\mathrm{H}_{2} \mathrm{O}_{2}$ concentrations. Large quantities of leaves, assigned DI $\geq 1$, were readily observable with the naked eye, providing growers a method to rapidly diagnose foliar $\mathrm{H}_{2} \mathrm{O}_{2}$ damage. As $\mathrm{H}_{2} \mathrm{O}_{2}$ concentration rose, leaves labeled DI 1 or 2 increasingly grouped together on the tray surface to provide an additional visual indicator of foliar phytotoxicity. Low damage rates, as was found in radish, may limit the applicability of this tactic because damaged leaves appeared sporadically throughout sampled cores. Despite this, leaf damage in all affected crops increased with concentration from 25 to $200 \mathrm{mg} \cdot \mathrm{L}^{-1}$, similar to the DI.

Variability in leaf damage between the tested species made developing a single threshold for $\mathrm{H}_{2} \mathrm{O}_{2}$ use difficult. The phytotoxic response to $\mathrm{H}_{2} \mathrm{O}_{2}$ foliar spray was focused on the outer leaf edges as mean DI values were relatively consistent, and the maximum percentage of damaged leaves varied from $<10 \%$ for radish (Fig. 1A) to $>50 \%$ for both 'Othilie' (Fig. 1C) and 'Rouxai' (Fig. 1D). On 
this basis, the commercial value of affected microgreen species or lettuce cultivars was not diminished by treatment with $50 \mathrm{mg} \cdot \mathrm{L}^{-1}$ for any of the crops. However, because both the percentage of damaged leaves and DI values doubled when the $\mathrm{H}_{2} \mathrm{O}_{2}$ concentration increased from 100 to 150 $\mathrm{mg} \cdot \mathrm{L}^{-1}$, a conservative estimate for $\mathrm{H}_{2} \mathrm{O}_{2}$ use may be required to limit potential crop losses when using this product. Crops with thicker leaves appear to be less affected by foliar spray, as suggested by the observed response of 'Black Oil' sunflower. The degree to which $\mathrm{H}_{2} \mathrm{O}_{2}$ penetrates the leaf cuticle remains unknown and may shed light on why 'Black Oil' sunflower was unaffected by $\mathrm{H}_{2} \mathrm{O}_{2}$ foliar spray.

\section{Conclusions}

Each crop in this study exhibited a distinctive response to foliar applications of $\mathrm{H}_{2} \mathrm{O}_{2}$ and thus required a unique threshold. For the described methodology, we recommend maximum $\mathrm{H}_{2} \mathrm{O}_{2}$ concentrations as follows: radish at $150 \mathrm{mg} \cdot \mathrm{L}^{-1}$, arugula at 100 $\mathrm{mg} \cdot \mathrm{L}^{-1}$, 'Othilie' lettuce at $125 \mathrm{mg} \cdot \mathrm{L}^{-1}$, 'Rouxai' lettuce at $75 \mathrm{mg} \cdot \mathrm{L}^{-1}$, and 'Xandra' lettuce at $125 \mathrm{mg} \cdot \mathrm{L}^{-1}$. Beyond these treatment concentrations, we found leaf damage advanced rapidly while becoming more easily visible to growers, and potentially consumers. Further, these concentrations will not cause a decrease in the physical growth of microgreen species or lettuce cultivars, a key aspect of marketing these high-value crops. Future studies should focus on continued phytotoxicity trials using the guidelines we have provided because it is evident that each crop type will exhibit a unique response to daily applications of $\mathrm{H}_{2} \mathrm{O}_{2}$.

\section{Literature cited}

Aftab, T., M. Masroor, A. Khan, M. Idrees, M. Naeem, N. Hashmi, Moinuddin, and M. Ram. 2011. Growth, photosynthetic efficiency and metabolic alterations associated with exogenous hydrogen peroxide in Artemisia annua: Overproduction of artemisinin. Russ. Agr. Sci. 37:212-219.

Ahmad, I., S.M.A. Basra, and A. Wahid. 2014. Exogenous application of ascorbic acid, salicylic acid and hydrogen peroxide improves the productivity of hybrid maize at low temperature stress. Intl. J. Agr. Biol. 16:825-830.

Ares, G., I. Martinez, C. Lareo, and P. Lema. 2008. Failure criteria based on con- sumers' rejection to determine the sensory shelf life of minimally processed lettuce. Postharvest Biol. Technol. 49:255-289.

Baldry, M.G.C. 1983. The bactericidal, fungicidal and sporicidal properties of hydrogen peroxide and peracetic acid. J. Appl. Bacteriol. 54:417-423.

Bosmans, L., B. van Calenberge, A. Paeleman, R. Moerkens, L. Wittemans, S. van Kerckhove, R. de Mot, B. Lievens, and H. Rediers. 2016. Efficacy of hydrogen peroxide treatment for control of hairy root disease caused by rhizogenic agrobacteria. J. Appl. Microbiol. 121:519-527.

Carrasco, G. and M. Urrestarazu. 2010. Green chemistry in protected horticulture: The use of peroxyacetic acid as a sustainable strategy. Intl. J. Mol. Sci. 11:1999-2009.

Coosemans, J. 1995. Control of algae in hydroponic systems. Acta Hort. 382:263-268.

Copes, W.E. 2009. Concentration and intervals of hydrogen peroxide applications to control Puccinia hemerocallidis on daylily. Crop Prot. 28:24-29.

Copes, W.E., G.A. Chastagner, and R.L. Hummel. 2003. Toxicity responses of herbaceous and woody ornamental plants to chlorine and hydrogen dioxides. Plant Health Prog., doi: 10.1094/PHP-20030311-01-RS.

Ehret, D.L., B. Alsanius, W. Wohanka, J.G. Menzies, and R. Utkhede. 2001. Disinfestation of recirculating nutrient solutions in greenhouse horticulture. Agronomie 21:332-339.

Elmer, W.H. 2008. Preventing the spread of fusarium wilt of hiemalis begonias in the greenhouse. Crop Prot. 27:1078-1083.

Fett, W.F. 2002. Reduction of the native microflora on alfalfa sprouts during propagation by addition of antimicrobial compounds to the irrigation water. Intl. J. Food Microbiol. 72:13-18.

Government of Canada. 2018. National Standard of Canada, Organic production systems: Permitted substances list. 8 Dec. 2018. <http://www.publications.gc.ca/ site/eng/9.854645/publication.html>.

Graham, T., P. Zhang, Y. Zheng, and M.A. Dixon. 2009. Phytotoxicity of aqueous ozone on five container-grown nursery species. HortScience 44:774-780.

James, W.C. 1971. An illustrated series of assessment keys for plant diseases, their preparation and usage. Can. Plant Dis. Surv. 51:39-65.

Klassen, N.V., D. Marchington, and H.C.E. McGowan. 1994. $\mathrm{H}_{2} \mathrm{O}_{2}$ determination by the $\mathrm{I}_{3}-$ method and by
$\mathrm{KMnO}_{4}$ titration. Anal. Chem. 66:29212925.

Nederhoff, E. 2000. Hydrogen peroxide for cleaning irrigation system. Commercial Grower 55(10):32-34.

Neill, S.J., R. Desikan, A. Clarke, R.D. Hurst, and J.T. Hancock. 2002. Hydrogen peroxide and nitric oxide as signalling molecules in plants. J. Expt. Bot. 53:1237-1247.

Petrov, V.D. and R. Van Breusegem. 2012. Hydrogen peroxide- a central hub for information flow in plant cells. AoB Plants 014:1-13.

Raudales, R.E., J.L. Parke, C.L. Guy, and P.R. Fisher. 2014a. Control of waterborne microbes in irrigation: A review. Agr. Water Mgt. 143:9-28.

Raudales, R.E., T.A. Irani, C.R. Hall, and P.R. Fisher. 2014b. Modified Delphi survey on key attributes for selection of water-treatment technologies for horticulture irrigation. HortTechnology 24:355-368.

Runia, W.T. 1995. A review of possibilities for disinfection of recirculation water from soilless cultures. Acta Hort. 382 221-229.

Runia, W.T. and J.J. Amsing. 1996. Disinfection of nematode-infested recirculation water by ozone and activated hydrogen peroxide. Proc. 9th Intl. Congr. Soilless Cult. p. 381-393.

Vanninen, I. and H. Koskula. 1998. Effect of hydrogen peroxide on algal growth, cucumber seedlings and the reproduction of shore flies (Scatella stagnalis) in rockwool. Crop Prot. 17:547-553.

Van, O.S.E. 1999. Closed soilless growing systems: A sustainable solution for Dutch greenhouse horticulture. Water Sci. Technol. 39:105-112.

Van Wyk, S.J.P., A.L. Boutigny, T.A. Coutinho, and A. Viljoen. 2012. Sanitation of a South African forestry nursery contaminated with Fusarium circinatum using hydrogen peroxide at specific oxidation reduction potentials. Plant Dis. 96:875-883.

Viršile, A. and R. Sirtautas. 2013. Light irradiance level for optimal growth and nutrient contents in borage microgreens. Proc. Intl. Sci. Conf. Rural Dev. 6:272275.

Xiao, Z., G.E. Lester, Y. Luo, and Q. Wang. 2015. Evaluation and correlation of sensory attributes and chemical compositions of emerging fresh produce. Microgreens. J. Agr. Food Chem. 110:140-148. 